INTERNATIONAL JOURNAL OF RESEARCHES IN BIOSCIENCES, AGRICULTURE AND TECHNOLOGY (C) VISHWASHANTI MULTIPURPOSE SOCIETY (Global Peace Multipurpose Society) R. No.MH-659/13(N) www.vmsindia.org

\title{
A STUDY OF PERCEPATIONS REGARDING MOSQUITO BORNE DISEASES IN AN URBAN AREA OF SOLAPURCITY (M.S)
}

\author{
R. K. Mane and A. C Kumbhar \\ Department of Zoology and Research Centre, \\ Sharkarrao Mohite Mahavidyalaya Akluj, Dist-Solapur \\ reshmamane21@gmail.com
}

\begin{abstract}
:
Mosquitoes are vectors for many deadly and debilitating human diseases such as malaria, yellow fever, dengue, zika etc. For developing a suitable and effective health education policy, it is inevitable to understand the level of knowledge of the community, their attitude and practices in mosquito born diseases. The present study was carried out in an urban area of Solapur city. Total 500 families were selected for survey by systematic random sampling. Data was collected using a semi-structured questionnaire during transmission season of mosquito born diseases. The collected data was analyzed and it is concluded that $90 \%$ respondents are agreed about the problem of mosquito and mosquito borne diseases. Government and people who are working in health sector intensified efforts towards creating public health education and mobilizing the community regarding the preventive measure they can take are important.
\end{abstract}

Keyw ords: Mosquito borne diseases, mosquitoes, questionnaire, urban community, health education.

\section{Introduction:}

Mosquitoes (Diptera: Culicidae) are now referred as 'Public Enemy No. 1' by the World Health Organization (WHO, 2009). There are more than 4500 species of mosquitoes distributed throughout the world under 34 genera; but mostly belongs to Aedes, Anopheles and Culex. They are vectors of several public and life threatening diseases including Malaria, Yellow fever, Dengue fever, Chikunguniya, Zika etc. These diseases are not only cause mortality or morbidity among the human and cause social, cultural, environmental and economic loss of the society. In recent year, vector borne diseases (VBD) are serious public health problems in countries in South- East Asia region, including India(Haung, 1972 and Whelan et al, 2001). It is recorded total 3565 cases and 24 deaths in Maharashtra due to dengue fever(Times of India 2 Nov 2014). Mosquito borne diseases are growing urban problems in Solapur city, because of unplanned urbanization, industrialization and irregular water supply etc. National Vector Borne Disease Control Programme (NVBDCP) is one of the most comprehensive and multifaceted public health activity including prevention and control of mosquito borne diseases (Brown MD, 1992). Community participation is essential for the awareness and control of an outbreak of mosquito borne diseases (Sherron DA and Rai KS, 1983). For the developing a suitable and effective health education strategy, it is helpful for understand and the level of knowledge of community, their attitude and practices in mosquito borne diseases. With this background it was decided to carry out this study in the urban locality of Solapur city in December 2014.

\section{Material and Methods:}

The present study was carried out in an urban area of Solapur city. Total 500 families were selected for study by systematic random sampling. Data was collected using a semistructured questionnaire during transmission season of mosquito borne diseases. The information was gathered using a semi structured questionnaires, which including questions related to perception of people on mosquitoes, their breeding sites, diseases spread, control measures, personal care used in community and source of treatment. Questionnaires were filled by door to door visit in study area.

\section{Results:}

Present study shows the observations based upon responses received from 500 respondents. Response to each question have been analysed separately. By the analysis of collected data it is found that, $90 \%$ of people agreed that mosquito as a problem for the public health.

Table No.1-4 show the observation different question was asked about mosquito borne diseases.

Table 1.- Knowledge about breeding sites of mosquitoes.

\begin{tabular}{|l|c|c|}
\hline $\begin{array}{c}\text { Answer for breeding } \\
\text { sites of mosquito }\end{array}$ & $\begin{array}{c}\text { Respondents } \\
(\mathrm{n}-500)\end{array}$ & $\%$ \\
\hline Drains/polluted water & 271 & 54.2 \\
\hline Clean water & 58 & 11.6 \\
\hline Garbage & 36 & 7.2 \\
\hline Don't know & 152 & 30.4 \\
\hline
\end{tabular}

Result shows that many people think that only polluted water is breeding site of mosquito 
which is not true.

Table 2.- Knowledge about mosquito borne diseases

\begin{tabular}{|l|c|c|}
\hline Name of the diseases & $\begin{array}{l}\text { Respondents } \\
(n-500\end{array}$ & $\%$ \\
\hline Malaria & 310 & 62.0 \\
\hline Dengue & 44 & 8.8 \\
\hline Zika and other diseases & 25 & 5.0 \\
\hline Don't Know & 187 & 37.4 \\
\hline
\end{tabular}

Result shows that most of the people know the knowledge about malaria only they don't have any information about new mosquito borne diseases like Zika.

Table 3.- Knowledge about personal care and control measures against mosquito bite.

\begin{tabular}{|l|c|c|}
\hline $\begin{array}{l}\text { Personal care and } \\
\text { control measures } \\
\text { against mosquito bite. }\end{array}$ & $\begin{array}{c}\text { Respondents } \\
(n-500\end{array}$ & $\%$ \\
\hline $\begin{array}{l}\text { Repellents (liquid, mat, } \\
\text { coil etc) }\end{array}$ & 307 & 61.4 \\
\hline Mosquito bed net & 51 & 10.2 \\
\hline $\begin{array}{l}\text { Screening of door and } \\
\text { windows }\end{array}$ & 15 & 3.0 \\
\hline Fan & 102 & 20.4 \\
\hline Don't know & 195 & 39.0 \\
\hline
\end{tabular}

Result shows that now a days people are aware about using repellent in personal care for protection by mosquito bite.
Table 4.-Knowledge about mosquito borne diseases treatment sources

\begin{tabular}{|l|c|c|}
\hline Treatment sources & $\begin{array}{c}\text { Respondents } \\
\text { (n-1 18) }\end{array}$ & $\mathbf{\%}$ \\
\hline $\begin{array}{l}\text { Government health } \\
\text { system }\end{array}$ & 16 & 13.6 \\
\hline Private practitioner & 80 & 67.8 \\
\hline Self medication & 13 & 11.0 \\
\hline Home remedy & 4 & 3.4 \\
\hline
\end{tabular}

Result shows that people are aware about treatment and medicine but the most of the people taken private treatment because there is no proper channel of government health system for vector borne diseases.

\section{Discussion:}

It can be concluded that intensified efforts towards creating public awareness and mobilizing the community regarding the prevention measures are needed. Information about breeding sites of mosquitoes, mortal outcomes of mosquito bite and control etc will be dispersed in human society for the awareness. So it can improve knowledge and awareness of community and thereby help in social mobilization of full involvement of the community in control of mosquito borne diseases.

\section{References:}

1. Brown M.D., M ottram P., Fanning I.D., Kay B. H. The peridomestic container-breeding mosquito fauna of Darnley Is. (Torres Strait) (Diptera: Culicidae), and the potential for its control by predacious Mesocyclops copepods. J Aust Ent Soc 1992; 31:305- 310.

2. Huang Y.M. The subgenus Stegomyia of Aedes in Southeast Asia. I - Thescutellaris group of species. Cont Am Ent Ins 1972;9:109.
3. Sherron D.A. and Rai K.S. Genetics of speciation in the Aedes (Stegomyia) scutellaris group (Dipera: Culicidae). J Med Entomol 1983;20:520-525.

4. Whelan P, Russell R.C., Hayes G., Tucker, G., Goodwin G. Exotic Aedes mosquitoes: onshore detection and elimination in Darwin, Northern Territory. Commun Dis Intell2001; 25: 283-285.

5. WHO. report VBD INDIA (2009) 